\title{
Absorption and endogenous excretion of phosphorus in growing broiler chicks, as influenced by calcium and phosphorus ratios in feed
}

\author{
BY M. R. AL-MASRI \\ Department of Radiation Agriculture, Atomic Energy Commission, PO Box 6091, Damascus, Syria
}

(Received 4 April 1994 - Revised 7 December 1994 - Accepted 6 January 1995)

\begin{abstract}
Absorption and endogenous excretion of $P$ by male broiler chicks (14-29 d old) were quantitatively evaluated at different $\mathrm{Ca}: \mathrm{P}$ ratios $(1,1: 1 ; 2,1.5: 1 ; 3,2: 1 ; 4,2.5: 1)$ in four groups given experimental diets $a d$ lib. The $P$ content was the same in all diets. An isotope-dilution technique was used to determine endogenous faecal and renal excretion. $C a$ and $P$ retentions in the whole body were estimated according to the comparative slaughter technique. $P$ absorption was calculated from retention and endogenous excretion. Absorption and endogenous excretion of $P$ amounted to $(\mathrm{mg} P / \mathrm{d}$ per chick): 304, 270, 160 and 158 ; and 135, 109, 31 and 30 in groups 1, 2, 3 and 4 respectively. Widening of the $C a: P$ ratio in the feed limited the $P$ absorption. Availability of feed $P$ amounted to (\%): (1) 66, (2) 57, (3) 32 and (4) 30, and the amounts of absorbed $P$ retained were (\%): (1) 56, (2) 60, (3 and 4) 81. The increasing $\mathrm{Ca}$ concentration in the feed showed a greater effect on $P$ absorption than on $P$ retention. The ratios of relative retention to relative endogenous excretion of absorbed $P$ were: (1) 1.27, (2) 1.50, (3 and 4) 4.26.
\end{abstract}

Phosphorus absorption: Endogenous phosphorus: Broilers: Ca:P ratios

Growth performance in poultry is related to the metabolism of minerals, especially Ca and $\mathbf{P}$, for bone formation. $\mathbf{P}$ metabolism is affected by the amount of $\mathbf{P}$ in the feed (Günther et al. 1982), the age of the animal and sources of $P$ supply (Günther et al. 1978; Günther \& Al-Masri, 1988), the amounts of $\mathrm{P}$ and $\mathrm{Ca}$ and the $\mathrm{Ca}: \mathrm{P}$ ratio in the feed (Günther \& Tekin, 1968a, b; Hermes, 1977) and phytase (EC 3.1.3.8) activity (Simons et al. 1990; Schöner et al. 1993) in addition to vitamin D supply.

In evaluating the metabolism of $P$ in the animal body and its influence on chick growth, $P$ absorption, retention of feed $P$, and endogenous $P$ excretion in relation to the $C a: P$ ratio in the feed are important variables that affect the supply of minerals to the skeleton. A radioisotope-dilution technique may be used to measure the endogenous faecal and renal $\mathbf{P}$ excretion. Absorbed $\mathbf{P}$ in relation to feed $\mathbf{P}$ gives $\mathbf{P}$ availability. In the same way, $\mathbf{P}$ retention in the whole body in relation to feed $\mathrm{P}$ gives the relative $\mathrm{P}$ retention. The present study provides quantitative information on the retention and endogenous excretion of absorbed $\mathbf{P}$, and evaluates the relationship between them for homeostasis of this mineral in growing chicks given diets with different $\mathrm{Ca}: \mathrm{P}$ ratios. $\mathrm{P}$ retention, endogenous $\mathrm{P}$ and $\mathrm{P}$ absorption were estimated at intervals between 14 and $29 \mathrm{~d}$ of age.

\section{MATERIALS AND METHODS}

Experimental design

The experiments were done with male broiler chicks ( $1 \mathrm{~d}$ old; Lohmann). This experiment lasted for $29 \mathrm{~d}$. The first $10 \mathrm{~d}$ were designated as a preparation period, during which 120 chicks were kept on the floor and fed on a conventional ration. The ambient temperature was 
$32^{\circ}$ in the first week, and lowered by $2^{\circ}$ for every successive week. The relative humidity was $50-60 \%$. On day 10 the chicks were transferred to metabolism cages. On day 14 eighty chicks of similar weight were divided into four groups (G1, G2, G3, G4) and each group was allocated to one of four diets which differed only in the $\mathrm{Ca}: \mathrm{P}$ ratio. On that day four birds (group $\mathrm{N}$ ) from each group were killed for assessment of the initial contents of Ca and $\mathrm{P}$ in the whole body. The remaining birds (sixteen per group) were kept in metabolism cages (two chicks per cage) until the 29th day. Also on the 14th day of age, each of the sixty-four chicks in the four experimental groups was injected intramuscularly with $1 \mathrm{ml}\left[{ }^{32} \mathrm{P}^{2} \mathrm{Na}_{3} \mathrm{PO}_{4}\right.$ solution (6.037 MBq) into the right breast muscle. On days 3, 7, 11 and 15 after injection, four chicks from each experimental group were slaughtered for assessment of the contents of $\mathrm{Ca}$ and $\mathrm{P}$ in the whole body. The blood plasma and excreta were also collected for analysis of stable and radioactive $P$.

\section{Statistical analyses}

A factorial type with complete randomized design was used in this experiment, with two factors: (1) diet as factor 1 with four levels (G1, G2, G3 and G4); (2) time as factor 2 with four levels $(3,7,11$ and $15 \mathrm{~d}$ after injection). Four diets were given to chicks in thirty-two cages and the chicks (in two cages/diet) were killed at four different times. Results were subjected to ANOVA using the Statview ${ }^{512}$ on a personal computer to test the effects of diet and time, and their interactions using Fisher's protected least significant difference at the 0.05 level. Means with their pooled standard error, $P$ values for diet, time, interactions and the residual degrees of freedom are presented.

\section{Diets}

The composition of the experimental diets is given in Table 1. Dicalcium phosphate $\left(\mathrm{CaHPO}_{4} .2 \mathrm{H}_{2} \mathrm{O}\right)$ and $\mathrm{CaCO}_{3}$ were added as supplemental $\mathrm{P}$ and $\mathrm{Ca}$ in experimental diets (G1, G2, G3, G4). During the period 14-29 d the chicks were fed ad lib. on the experimental diets. The diets were not pelleted. The chicks were offered distilled water. The dry matter intake was measured quantitatively for the experimental days and the $\mathrm{P}$ and $\mathrm{Ca}$ consumed were assessed to calculate relative retention or availability values.

\section{Analytical methods}

The levels of radioactive $P$ in plasma and excreta were determined on days 3, 7, 11 and 15 after the injection with ${ }^{32} \mathrm{P}$ by liquid scintillation counting and with the help of Cerenkovradiation according to Vemmer \& Gütte (1964). The stable $P$ in the ash of samples was determined according to the method of Lantzsch (1961), and the $P$ in plasma was estimated with the help of a test kit (Test-Combination. Phosphorus, Phospholipids. Colorimetric method. Cat. no. 124974; Boehringer, Mannheim, Germany). The Ca concentration was determined by atomic absorption spectrometry. The endogenous $\mathbf{P}$ in the excreta was estimated according to a radioisotope-dilution technique (Hevesey, 1948, 1962). Specific radioactivity in excreta $(\mathrm{Bq} / \mathrm{mg} \mathrm{P})$ to specific radioactivity in blood plasma $(\mathrm{Bq} / \mathrm{mg} \mathrm{P})$ multiplied by the amount of $P$ in excreta $(\mathrm{mg} P / d$ per chick) gives the endogenous $P$ in excreta (mg P/d per chick). Ca and $\mathrm{P}$ retentions in the whole body ( $\mathrm{mg} / \mathrm{d}$ per chick) were assessed according to the comparative slaughter technique from the difference between the $\mathrm{Ca}$ and $\mathrm{P}$ retentions at $17,21,25$ and $29 \mathrm{~d}$ of age (mg $\mathrm{P}$ or $\mathrm{Ca} / \mathrm{d}$ per chick) and those at $14 \mathrm{~d}$ of age (mg $\mathrm{P}$ or $\mathrm{Ca} / \mathrm{d}$ per chick) (group $\mathrm{N}$ ). $\mathrm{P}$ retained in the body (mg P/d per chick) and endogenous $P$ in excreta (mg $P / d$ per chick) constitute $P$ absorbed (mg P/d per chick). 
Table 1. Composition of the experimental diets

\begin{tabular}{|c|c|c|c|c|}
\hline Diet.. & G1 & G2 & G3 & G4 \\
\hline \multicolumn{5}{|l|}{ Ingredient $(\mathrm{g} / \mathrm{kg})$} \\
\hline Yellow maize & $195 \cdot 0$ & $200 \cdot 0$ & $190 \cdot 0$ & 190.0 \\
\hline Sorghum & $195 \cdot 0$ & $195 \cdot 0$ & $190 \cdot 0$ & $190 \cdot 0$ \\
\hline Soyabean meal & $300 \cdot 0$ & $290 \cdot 0$ & 293.0 & $290 \cdot 0$ \\
\hline Wheat & $100 \cdot 0$ & $95 \cdot 0$ & $100 \cdot 0$ & 95.0 \\
\hline Maize starch & $100 \cdot 0$ & $100 \cdot 0$ & $100 \cdot 0$ & $100-0$ \\
\hline Lucerne meal & 42.5 & $43 \cdot 4$ & $41 \cdot 2$ & $40 \cdot 1$ \\
\hline Casein & $32 \cdot 0$ & $32 \cdot 0$ & $32 \cdot 0$ & $32 \cdot 0$ \\
\hline Skimmed milk & $18 \cdot 0$ & $18 \cdot 0$ & $18 \cdot 0$ & $18 \cdot 0$ \\
\hline $\mathrm{NaCl}$ & $2 \cdot 0$ & $2 \cdot 0$ & $2 \cdot 0$ & $2 \cdot 0$ \\
\hline Dicalcium phosphate & $12 \cdot 3$ & $12 \cdot 3$ & $12 \cdot 3$ & $12 \cdot 3$ \\
\hline Calcium carbonate & $0 \cdot 2$ & $9 \cdot 3$ & 18.5 & 27.6 \\
\hline Minerals* & 1.0 & $1 \cdot 0$ & 1.0 & $1 \cdot 0$ \\
\hline Vitamins $\dagger$ & $2 \cdot 0$ & $2 \cdot 0$ & $2 \cdot 0$ & $2 \cdot 0$ \\
\hline \multicolumn{5}{|l|}{ Composition (g/kg DM) } \\
\hline $\mathrm{DM}(\mathrm{g} / \mathrm{kg})$ & $924 \cdot 3$ & $924 \cdot 3$ & 929.9 & $927 \cdot 7$ \\
\hline Crude ash & $59 \cdot 6$ & $59 \cdot 3$ & $67 \cdot 3$ & $72 \cdot 5$ \\
\hline Crude protein & $235 \cdot 0$ & 233.4 & $235 \cdot 6$ & $233 \cdot 1$ \\
\hline Crude fat & $30 \cdot 5$ & 31.9 & 28.9 & $29 \cdot 8$ \\
\hline Crude fibre & 35.8 & $35 \cdot 5$ & $35 \cdot 4$ & $36 \cdot 4$ \\
\hline $\mathrm{Ca}$ & 6.6 & $9 \cdot 6$ & $12 \cdot 6$ & $15 \cdot 8$ \\
\hline Total P & 6.5 & $6 \cdot 4$ & 6.4 & $6 \cdot 3$ \\
\hline Organic $\mathrm{P}$ & $2 \cdot 4$ & $2 \cdot 4$ & $2 \cdot 4$ & $2 \cdot 4$ \\
\hline $\mathrm{Ca}: \mathrm{P}$ ratio & $1 \cdot 01: 1$ & $1 \cdot 50: 1$ & $1.97: 1$ & $2 \cdot 51: 1$ \\
\hline Metabolizable energy $(\mathrm{MJ} / \mathrm{kg})$ & $12 \cdot 23$ & $12 \cdot 36$ & $12 \cdot 25$ & $12 \cdot 27$ \\
\hline
\end{tabular}

* Supplied (/kg diet): $\mathrm{MnO}_{2} 35.0 \mathrm{mg}, \mathrm{ZnO} 25.0 \mathrm{mg}, \mathrm{FeSO}_{4} 25.0 \mathrm{mg}, \mathrm{CuSO}_{4} 2.5 \mathrm{mg}, \mathrm{CaI}_{2} 0.25 \mathrm{mg}, \mathrm{CoCO}_{3}$ $0.10 \mathrm{mg}$, Se $0.05 \mathrm{mg}$, available $\mathrm{P} 0.10 \mathrm{~g}, \mathrm{Ca} 0.23 \mathrm{~g}$.

† Supplied (/kg diet): retinol $3 \mathrm{mg}$, cholecalciferol $0.05 \mathrm{mg}$, $\alpha$-tocopherol $5 \mathrm{mg}$, menadione $2.0 \mathrm{mg}$, thiamin $1.0 \mathrm{mg}$, riboflavin $2.5 \mathrm{mg}$, pyridoxine $2.0 \mathrm{mg}$, cyanocobalamin $0.01 \mathrm{mg}$, pteroylmonoglutamic acid $0.4 \mathrm{mg}$, calcium pantothenate $5.0 \mathrm{mg}$, nicotinamide $20.0 \mathrm{mg}$.

\section{RESULTS}

Table 2 gives the endogenous $\mathbf{P}$ and $\mathbf{P}$ absorption values used to test the effects of diet, time and their interactions. Endogenous $P$ in excreta decreased as Ca concentration in the feed was increased. The mean levels of endogenous $P$ in excreta over the experimental period were (mg P/d per chick): (G1) 135, (G2) 109, (G3) 31 and (G4) 30. P absorption is the sum of $\mathbf{P}$ retention and endogenous $\mathbf{P}$ in excreta. $\mathbf{P}$ absorption decreased with increasing $\mathrm{Ca}$ concentration in the feed. Table 3 gives the comparison between group $1(=100)$ and the other experimental groups for endogenous $\mathrm{P}$ excretion, retained $\mathrm{P}$ and $\mathrm{P}$ absorbed. The effect of the concentration of $\mathrm{Ca}$ in feed (with the constant concentration of $\mathrm{P}$ ) on $\mathrm{P}$ absorption was higher than that of $P$ retention. The mean levels of retained $P$ in the whole body during the experiment were (mg P/d per chick): (G1) 169, (G2) 161, (G3) 129 and (G4) 128. Fig. 1 shows the changes in $P$ retained in the whole body as affected by the $\mathrm{Ca}: \mathrm{P}$ ratio in the feed.

The average feed intakes over the experimental period were (g/d per chick): (G1) 70 , (G2) 73, (G3) 75 and (G4) 81. Table 4 indicates the amounts of $P$ and Ca consumed (mg/d per chick) on the experimental days. $\mathrm{P}$ absorbed : $\mathrm{P}$ consumed from feed $(\mathrm{mg} \mathrm{P} / \mathrm{d}$ per chick) $\times 100$ gives $\mathrm{P}$ availability $(\%)$. $\mathrm{P}$ or $\mathrm{Ca}$ retention in the body $(\mathrm{mg} \mathrm{P}$ or $\mathrm{Ca} / \mathrm{d}$ per chick) : $\mathrm{P}$ or $\mathrm{Ca}$ consumed from feed $(\mathrm{mg} \mathrm{P}$ or $\mathrm{Ca} / \mathrm{d}$ per chick) $\times 100$ gives the relative $\mathrm{P}$ or $\mathrm{Ca}$ retention $(\%)$ (Table 5). The experiments indicated a decrease in relative Ca retention 
Table 2. Influence of the calcium:phosphorus ratio of the diet* on daily excretion of endogenous phosphorus in faeces and phosphorus absorption into the body of growing chicks ( $m g$ P/d per chick) from 3 to $15 d$ after injection with ${ }^{32} P \dagger$

(Mean values with their pooled standard error)

\begin{tabular}{|c|c|c|c|c|c|c|c|c|c|c|}
\hline \multirow[b]{2}{*}{$\begin{array}{l}\text { Time after } \\
\text { injection } \\
\text { (d) }\end{array}$} & \multicolumn{5}{|c|}{ Endogenous $P \ddagger$} & \multicolumn{5}{|c|}{ P absorption $\ddagger$} \\
\hline & G1 & G2 & G3 & G4 & $\begin{array}{l}\text { Pooled } \\
\text { SE } \\
\text { (df 16) }\end{array}$ & G1 & G2 & G3 & $\mathrm{G} 4$ & $\begin{array}{l}\text { Pooled } \\
\text { SE } \\
\text { (df 16) }\end{array}$ \\
\hline 3 & 76 & 74 & 21 & 19 & 10.6 & 181 & 169 & 72 & 69 & $20 \cdot 0$ \\
\hline 7 & 113 & 87 & 33 & 37 & 12.9 & 277 & 236 & 152 & 165 & 19.7 \\
\hline 11 & 145 & 122 & 31 & 32 & $19 \cdot 7$ & 332 & 304 & 185 & 185 & 25.7 \\
\hline 15 & 208 & 153 & 40 & 31 & 28.4 & 427 & 371 & 233 & 213 & $34 \cdot 2$ \\
\hline $\begin{array}{l}\text { Pooled SE } \\
\text { (df 16) }\end{array}$ & $18 \cdot 3$ & $12-0$ & $2 \cdot 8$ & $2 \cdot 7$ & & 33.6 & $28 \cdot 7$ & $22 \cdot 5$ & $20 \cdot 6$ & \\
\hline
\end{tabular}

* Ca:P ratios of the diets were: G1, 1.01:1; G2, 1.50:1; G3, 1.97:1; G4, 2.50:1.

$\uparrow$ For details of diets and procedures, see Table 1 and pp. 407-408.

¥ Statistical significance of effect of $\operatorname{diet}(\mathrm{D}), P<0.0001$; time (T), $P<0.0001 ; \mathrm{D} \times \mathrm{T}$ interaction, $P<0.0001$. For endogenous $P$, s (square root of residual mean square) $=7 \cdot 1$; for $P$ absorption $s=10 \cdot 3$.

Table 3. Excretion of endogenous phosphorus, phosphorus retention and phosphorus absorption by chicks fed on diets with different calcium:phosphorus ratios*, from 3 to $15 d$ after injection with ${ }^{32} P \dagger$

(Values are expressed as a proportion of those obtained with a calcium:phosphorus ratio of $1.01: 1$ )

\begin{tabular}{|c|c|c|c|c|c|c|c|c|c|c|}
\hline \multirow{2}{*}{$\begin{array}{l}\text { Time after } \\
\text { injection } \\
\text { (d) }\end{array}$} & \multicolumn{4}{|c|}{ Endogenous P } & \multicolumn{3}{|c|}{$P$ retention } & \multicolumn{3}{|c|}{$\mathbf{P}$ absorption } \\
\hline & G1 & $\mathrm{G} 2$ & $\mathrm{G} 3$ & $\mathrm{G} 4$ & $\mathrm{G} 2$ & G3 & G4 & $\mathrm{G} 2$ & $\mathrm{G} 3$ & G4 \\
\hline 3 & 100 & 97 & 28 & 25 & 90 & 48 & 48 & 93 & 40 & 38 \\
\hline 7 & 100 & 77 & 29 & 33 & 91 & 72 & 79 & 85 & 55 & 60 \\
\hline 11 & 100 & 84 & 21 & 22 & 99 & 82 & 82 & 100 & 61 & 61 \\
\hline 15 & 100 & 73 & 19 & 14 & 99 & 88 & 83 & 87 & 55 & 50 \\
\hline Mean & 100 & 83 & 24 & 23 & 95 & 72 & 73 & 91 & 53 & 52 \\
\hline
\end{tabular}

* $\mathrm{Ca}: \mathrm{P}$ ratios of the diets were: $\mathrm{G} 1,1.01: 1 ; \mathrm{G} 2,1 \cdot 50: 1 ; \mathrm{G} 3,1 \cdot 97: 1 ; \mathrm{G} 4,2 \cdot 50: 1$.

$\dagger$ For details of diets and procedures, see Table 1 and pp. 407-408.

of feed $\mathrm{Ca}$ with an increase in the concentration of feed $\mathrm{Ca}$, and relative $\mathrm{P}$ retention of feed $P$ also decreased when comparing groups 1 and 2 with 3 and 4 . This is attributed to the low rate of $\mathbf{P}$ absorption. Moreover, $\mathrm{Ca}: \mathbf{P}$ retention in the body increased with increasing $\mathrm{Ca}$ concentration in the feed. $\mathrm{Ca}: P$ retention reached an average for the whole experimental period of (G1) 1.21, (G2) 1.25, (G3) 1.70 and (G4) 1.71. Relative P retention is clearly connected to the relative Ca retention $\left(R^{2} 0 \cdot 815\right)$. An increase in the Ca concentration of feed limits $P$ retention in the body. The comparison between $G 1$ (100) and the other experimental groups shows that relative $P$ retention values during the whole experiment were: (G2) 92, (G3) 70 and (G4) 65. Fig. 2 gives the $P$ availability of feed $P$ as influenced by the $\mathrm{Ca}: \mathrm{P}$ ratio of the feed. Availability of feed $\mathrm{P}$ amounted on average to $(\%):(\mathrm{Gl})$ 66, (G2) 57, (G3) 32 and (G4) 30. The comparison between G1 (100) and the other experimental groups shows that the $P$ availability values were: (G2) 86, (G3) 48 and (G4) 


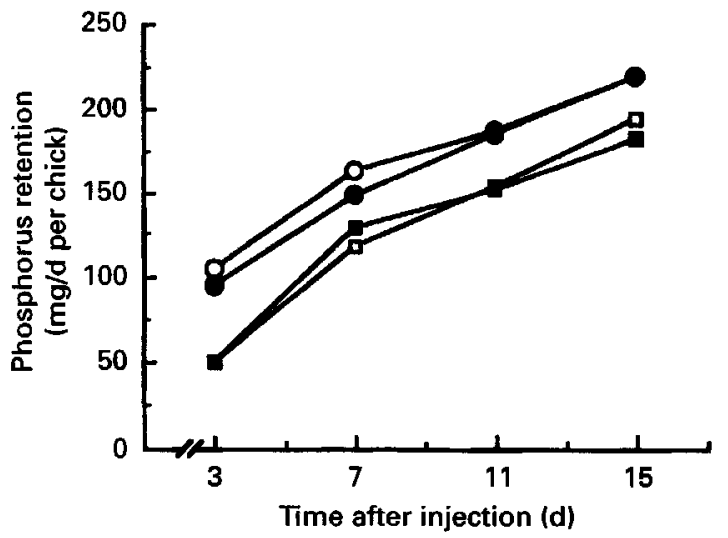

Fig. 1. Influence of the calcium: phosphorus ratio of the diet on daily retention of phosphorus (mg $P / d$ per chick) in the whole body of growing chicks, from 3 to $15 \mathrm{~d}$ after injection of ${ }^{32} \mathrm{P}$. Ca:P ratios of the diets were: $(O)$,

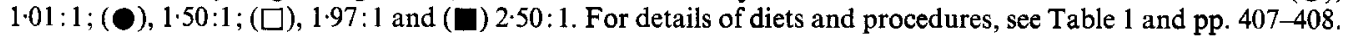

Table 4. Amounts of calcium and phosphorus ( $m$ g/d per chick) consumed by growing chicks fed on diets with different calcium:phosphorus ratios* from 3 to 15 d after injection of ${ }^{32} P \dagger$

(Mean values with their pooled standard errors)

\begin{tabular}{|c|c|c|c|c|c|c|c|c|c|c|}
\hline \multirow[b]{2}{*}{$\begin{array}{l}\text { Time after } \\
\text { injection } \\
\text { (d) }\end{array}$} & \multicolumn{5}{|c|}{$\mathrm{P}$ consumed $\ddagger$} & \multicolumn{5}{|c|}{$\mathrm{Ca}$ consumed§ } \\
\hline & G1 & G2 & G3 & G4 & $\begin{array}{l}\text { Pooled } \\
\text { SE } \\
\text { (df 16) }\end{array}$ & G1 & $\mathrm{G} 2$ & G3 & G4 & $\begin{array}{c}\text { Pooled } \\
\text { SE } \\
\text { (df 16) }\end{array}$ \\
\hline 3 & 287 & 318 & 302 & 308 & $5 \cdot 7$ & 282 & 463 & 567 & 697 & 58.2 \\
\hline 7 & 421 & 405 & 431 & 457 & 7.8 & 414 & 598 & 806 & 1116 & 98.7 \\
\hline 11 & 516 & 565 & 572 & 588 & $13 \cdot 2$ & 509 & 830 & 1068 & 1416 & $127 \cdot 1$ \\
\hline 15 & 608 & 591 & 663 & 734 & $22 \cdot 8$ & 643 & 873 & 1257 & 1771 & 162.0 \\
\hline $\begin{array}{l}\text { Pooled SE } \\
\text { (df 16) }\end{array}$ & $45 \cdot 0$ & $43 \cdot 7$ & $52 \cdot 5$ & $59 \cdot 7$ & & $50 \cdot 0$ & 65.2 & $100 \cdot 9$ & $149 \cdot 4$ & \\
\hline
\end{tabular}

* Ca:P ratios of the diets were: $\mathrm{G} 1,1 \cdot 01: 1 ; \mathrm{G} 2,1 \cdot 50: 1 ; \mathrm{G} 3,1 \cdot 97: 1 ; \mathrm{G} 4,2 \cdot 50: 1$.

$\dagger$ For details of diets and procedures, see Table 1 and pp. 407-408.

\$ Statistical significance of effect of diet (D), $P<0.0004$; time (T), $P<0.0001$ and D $\times$ T, $P=0.0284$.

$\S$ Statistical significance of effect of $\mathrm{D}, P<0.0001, \mathrm{~T}, P<0.0001$ and $\mathrm{D} \times \mathrm{T}, P<0.0001$. For $\mathrm{P}$ consumed, $s$ (square root of residual mean square) $=24 \cdot 3 ;$ for Ca consumed, $s=50 \cdot 9$.

45. Table 6 indicates the relationship of $P$ absorption and $P$ retention to endogenous $P$ excretion, and shows decreases in $\mathbf{P}$ absorption with increasing $\mathrm{Ca}: \mathrm{P}$ ratio in the diet. This is attributed to the decreases in $\mathrm{P}$ retention and endogenous $\mathrm{P}$ excretion. The latter has a higher effect than $\mathrm{P}$ retention in this case. Since the endogenous $\mathrm{P}$ excretion : $\mathrm{P}$ absorption ratio decreases more than the $P$ retention : $P$ absorption ratio, the ratio of relative retention to relative endogenous $P$ excretion is clearly increased by a wide ratio of $\mathrm{Ca}: \mathrm{P}$ in the diet.

The values of $\mathrm{Ca}$ retention in the whole body were similar among the experimental groups despite the differences of $\mathrm{Ca}: \mathrm{P}$ ratio in the feeds. These values were on average (mg $\mathrm{Ca} / \mathrm{d}$ per chick): (G1) 201, (G2) 198, (G3) 191 and (G4) 195, whereas a difference in the relative $\mathrm{Ca}$ retention of feed $\mathrm{Ca}$ was found among the experimental groups. The comparison between $\mathrm{Gl}(100)$ and the other experimental groups shows that the values of relative Ca retention during the experiment were: (G2) 66, (G3) 48 and (G4) 37. 
Table 5. Influence of the calcium:phosphorus ratio of the diet* on relative retention of calcium and phosphorus (\%) by growing chicks, from 3 to $15 \mathrm{~d}$ after injection with ${ }^{32} \mathrm{P} \dagger$

(Mean values with their pooled standard error)

\begin{tabular}{|c|c|c|c|c|c|c|c|c|c|c|}
\hline \multirow{2}{*}{$\begin{array}{l}\text { Time after } \\
\text { injection } \\
\text { (d) }\end{array}$} & \multicolumn{5}{|c|}{ Relative $\mathbf{P}$ retention $\ddagger$} & \multicolumn{5}{|c|}{ Relative Ca retention $\S$} \\
\hline & G1 & $\mathrm{G} 2$ & G3 & G4 & $\begin{array}{l}\text { Pooled SE } \\
\text { (df 16) }\end{array}$ & G1 & G2 & G3 & $\mathrm{G} 4$ & $\begin{array}{l}\text { Pooled SE } \\
\text { (df 16) }\end{array}$ \\
\hline 3 & $37 \cdot 5$ & $30 \cdot 5$ & $17 \cdot 0$ & $18 \cdot 0$ & $3 \cdot 4$ & $46 \cdot 5$ & $28 \cdot 0$ & $23 \cdot 5$ & $19 \cdot 0$ & $4 \cdot 0$ \\
\hline 7 & $39 \cdot 0$ & $37 \cdot 0$ & $28 \cdot 0$ & $28 \cdot 5$ & 1.9 & $48 \cdot 0$ & $33 \cdot 5$ & $23 \cdot 0$ & $17 \cdot 5$ & $4 \cdot 4$ \\
\hline 11 & $36 \cdot 5$ & $32 \cdot 5$ & $28 \cdot 5$ & $26 \cdot 5$ & $1 \cdot 5$ & $41 \cdot 5$ & $25 \cdot 5$ & $19 \cdot 5$ & $15 \cdot 5$ & $3 \cdot 8$ \\
\hline 15 & $36 \cdot 0$ & $37 \cdot 0$ & $30 \cdot 0$ & $25 \cdot 5$ & 1.8 & $40 \cdot 5$ & $28 \cdot 5$ & $19 \cdot 0$ & $13 \cdot 5$ & 3.9 \\
\hline $\begin{array}{l}\text { Pooled SE } \\
\text { (df 16) }\end{array}$ & $0 \cdot 8$ & $1 \cdot 1$ & $2 \cdot 1$ & 1.6 & & $1 \cdot 3$ & $1 \cdot 1$ & $1 \cdot 0$ & 0.8 & \\
\hline
\end{tabular}

* Ca:P ratios of the diets were: $\mathrm{G} 1,1 \cdot 01: 1 ; \mathrm{G} 2,1 \cdot 50: 1 ; \mathrm{G} 3,1 \cdot 97: 1 ; \mathrm{G} 4,2 \cdot 50: 1$.

$\uparrow$ For details of diets and procedures, see Table 1 and pp. 407-408.

$\ddagger$ Statistical significance of effect of diet (D), $P<0-0001$, time $(\mathrm{T}), P<0-0001$, and $\mathrm{D} \times \mathrm{T}$ interaction, $P=0.0037$.

$\S$ Statistical significance of effect of D, $P<0.0001, \mathrm{~T}, P<0.0001, \mathrm{D} \times \mathrm{T}, P<0.0914$. For relative $\mathrm{P}$ retention, $\mathrm{s}$ (square root of residual mean square) $=1.9 ;$ for $\mathrm{Ca}$ retention, $\mathrm{s}=1.7$.

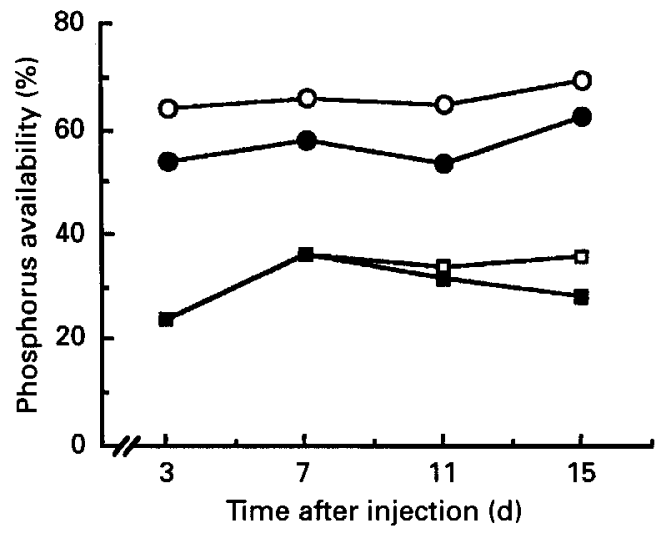

Fig. 2. Influence of the calcium:phosphorus ratio of the diet on the relative availability of feed phosphorus to growing chicks, from 3 to $15 \mathrm{~d}$ after injection of ${ }^{32} \mathrm{P}$. Ca:P ratios of the diets were: $(\mathrm{O}), 1 \cdot 01: 1 ;(\mathbf{O}), 1 \cdot 50: 1 ;(\square)$, 1.97:1 and (ロ 2.50:1. For details of diets and procedures, see Table 1 and pp. 407-408.

\section{DISCUSSION}

This study investigated the metabolic interactions between the retention and endogenous excretion of absorbed $\mathbf{P}$ from feed, with changes in dietary $\mathrm{Ca}: \mathrm{P}$ ratio. These interactions have an important influence on the contents of minerals in the body of growing animals, especially in bones. These experiments provide important information with which to determine the $\mathbf{P}$ requirements of growing chicks to improve their growth performance. The growth rate and the retained minerals in bones are affected by the content of organic phytate-P and the range of $\mathrm{Ca}: \mathrm{P}$ ratio in feed (Scharifi, 1978). A high $\mathrm{Ca}$ concentration in feed has a negative effect on phytin hydrolysis (Schultz \& Oslage, 1972), and leads to a decrease in $\mathbf{P}$ utilization (Huyghebaert et al. 1981). The faecal excretion of $\mathrm{Ca}$ and $\mathrm{P}$ increases with increasing dietary levels (Damron et al. 1975). Hermes et al. (1983) reported 
Table 6. Relationship of phosphorus absorption and phosphorus retention in the whole body, to endogenous phosphorus excretion ( $m g$ P/d per chick) in growing chicks fed on diets with different calcium:phosphorus ratios* ${ }^{*}$

(Mean values for the entire experimental period)

\begin{tabular}{lrrrrr}
\hline & $\mathrm{G} 1$ & $\mathrm{G} 2$ & $\mathrm{G3}$ & $\mathrm{G} 4$ \\
\hline Absorption (Ab) & 304 & 270 & 160 & 158 \\
Retention (Re) & 169 & 161 & 129 & 128 \\
Endogenous excretion (Ex) & 135 & 109 & 31 & 30 \\
Re/Ab $\times 100$ & 56 & 60 & 81 & 81 \\
Ex/Ab $\times 100$ & 44 & 40 & 19 & 19 \\
Relative Re/relative Ex & 1.27 & 1.50 & 4.26 & 4.26 \\
\hline
\end{tabular}

* Ca:P ratios of the diets were: G1, $1.01: 1 ; \mathrm{G} 2,1 \cdot 50: 1 ; \mathrm{G} 3,1 \cdot 97: 1 ; \mathrm{G} 4,2 \cdot 50: 1$.

$\dagger$ For details of diets and procedures, see Table 1 and pp. 407-408.

that $\mathrm{P}$ absorption decreased with increasing width of $\mathrm{Ca}: \mathrm{P}$ ratio in the feed of growing chicks and the amounts excreted from injected ${ }^{32} \mathrm{P}$ were 45,31 and $9 \%$ at $\mathrm{Ca}: \mathrm{P}$ ratios of $0 \cdot 66: 1,1 \cdot 5: 1$ and $2 \cdot 5: 1$ respectively. The efficiency of utilization of feed $P$ for retention in the body amounted to $39 \%(0 \cdot 66: 1), 62 \%(1 \cdot 5: 1$ and $2 \cdot 5: 1)$. Further increasing the $\mathrm{Ca}$ intake above $440 \mathrm{mg} / \mathrm{d}$ progressively depressed the absorption of P (Hurwitz et al. 1978). This is in agreement with our results where $P$ availability reached $66,57,32$ and $30 \%$ when using $\mathrm{Ca}: \mathrm{P}$ ratios of $1: 1,1 \cdot 5: 1,2: 1$, and $2 \cdot 5: 1$ respectively. Relative $\mathrm{P}$ retention amounted to $33 \%$ for growing chicks given feed containing $6.0 \mathrm{~g}$ total $\mathrm{P} / \mathrm{kg}$, of which $1.4 \mathrm{~g}$ was organic phytate-P, with a Ca:P ratio of 1.68:1 (Günther \& Al-Masri, 1988). In the present experiments, relative $\mathrm{P}$ retention amounted to $34 \%$ at a $\mathrm{Ca}: \mathrm{P}$ ratio of $1 \cdot 5: 1$. Further increases in the ratio led to decreases in relative $\mathbf{P}$ retention.

Ou results indicate that values for the specific ratio of the radioactivity of ${ }^{32} \mathrm{P}$ in excreta to the specific radioactivity of ${ }^{32} \mathrm{P}$ in plasma were: (G1) $0 \cdot 678: 1,(\mathrm{G} 2) 0 \cdot 568: 1,(\mathrm{G} 3) 0 \cdot 165: 1$ and (G4) $0 \cdot 146: 1$. According to Hevesey $e t$ al. (1939) and Hevesey $(1948,1962)$ the radioactivity of ${ }^{32} \mathrm{P}$ of endogenous $\mathrm{P}$ in faeces must be equal to the radioactivity of ${ }^{32} \mathrm{P}$ of the inorganic $\mathbf{P}$ in blood plasma, at the total absorption of feed $P$.

An increase in feed phytate-P limits endogenous $\mathbf{P}$ excretion and decreases $\mathbf{P}$ absorption (Günther et al. 1978) and also decreases relative $\mathrm{Ca}$ retention of feed $\mathrm{Ca}$ at constant $\mathrm{Ca}: \mathrm{P}$ ratio in the feed (Günther \& Al-Masri, 1988). The latter authors reported that 29 (group 1), 34 (group 2), 35 (group 3) and 64\% (group 4) of the absorbed $P$ was retained in the body and the endogenous $P$ excretions were $249,160,90$ and $38 \mathrm{mg} / \mathrm{d}$ per chick respectively. Group 1 contained only $6.2 \mathrm{~g}$ inorganic $\mathrm{P} / \mathrm{kg} \mathrm{DM}$, group 2 contained $6.0 \mathrm{~g}$ total $\mathrm{P} / \mathrm{kg} \mathrm{DM}$ in which $1.4 \mathrm{~g} / \mathrm{kg} \mathrm{DM}$ was organic phytate-P. Group 3 contained $6.5 \mathrm{~g}$ total $\mathrm{P} / \mathrm{kg} \mathrm{DM}$ in which $3.3 \mathrm{~g} / \mathrm{kg} \mathrm{DM}$ was organic phytate-P. Group 4 contained $3.2 \mathrm{~g}$ only inorganic $\mathrm{P} / \mathrm{kg}$ DM. In comparison, our results indicated that $56(\mathrm{G} 1), 60$ (G2) and $81 \%$ (G3 and G4) of P absorbed was retained, and the endogenous P excretion amounted to ( $\mathrm{mg}$ $\mathrm{P} / \mathrm{d}$ per chick): $135,109,30$ and 31 respectively. Comparing the results of Günther \& AlMasri (1988) with the present results, we conclude that the effect of $\mathrm{Ca}$ concentration in the diet on endogenous $\mathrm{P}$ excretion and $\mathrm{P}$ absorption is higher than the effect of phytate-P and the latter is higher than the effect of total $P$ in the diet.

The rate of relative $P$ retention to relative endogenous $P$ excretion increased with increasing $\mathrm{Ca}$ concentration in the feed. Our results indicate that, if $100 \mathrm{mg} P$ were absorbed daily, then the amounts of endogenous $P$ excreted would be $44,40,19$ and $18 \mathrm{mg}$ 
for groups 1, 2, 3 and 4 respectively. However, Abel et al. (1982) reported that total $\mathrm{P}$ absorbed per animal amounted to $3759 \mathrm{mg}$ during a $14 \mathrm{~d}$ experimental period, and $2459 \mathrm{mg}$ $\mathrm{P} /$ animal was retained. Chickens were fed $a d \mathrm{lib}$. on a phytic acid-free diet containing $5 \mathrm{~g}$ $\mathrm{P} / \mathrm{kg} \mathrm{DM}$ and $7.5 \mathrm{~g} \mathrm{Ca} / \mathrm{kg} \mathrm{DM}$.

The results indicate that the difference between absorbed $\mathbf{P}$ and $\mathbf{P}$ retention in the body was most clearly observed at narrow $\mathrm{Ca}: \mathrm{P}$ ratios in the feed, which can be accounted for by the high rates of endogenous $\mathrm{P}$ excretion. The difference between $\mathrm{P}$ availability and relative retention of feed $\mathrm{P}$ was $29 \%$ for $\mathrm{Gl}(\mathrm{Ca}: \mathrm{P} 1: 1)$ and $6 \%$ for $\mathrm{G} 4(\mathrm{Ca}: \mathrm{P} 2 \cdot 5: 1)$. $\mathrm{P}$ availability of feed $P$ decreased at wide $\mathrm{Ca}: \mathrm{P}$ ratios in the feed due to the low amount of endogenous $\mathrm{P}$ excretion and the increase in Ca concentration of the feed, where $\mathrm{Ca}$ limits the absorption of $\mathbf{P}$ and decreases endogenous $\mathbf{P}$ in urine. It is apparent that the kidney plays an important role in the regulation of $\mathbf{P}$ absorption and thus in its homeostasis in the body.

The author would like to thank the Director General and the Head of Radiation Agriculture in the Atomic Energy Commission of Syria for their support. For the scientific help, the author would like to thank Prof. K. D. Günther, Institute of Animal Physiology and Nutrition, University of Göttingen, Germany.

\section{REFERENCES}

Abel, H., Hermes, I. \& Günther, K. D. (1982). Untersuchungen zur intermediären Verfügbarkeit und Verwertbarkeit des Futterphosphors beim wachsenden Geflügel. 1. Methodische Voraussetzungen (Evaluation of the intermediary availability and the efficiency of utilization of feed phosphorus in growing chickens. 1 . Methodological assumptions). Zeitschrift für Tierphysiologie, Tierernährung und Futtermittelkunde 48, 154-159.

Damron, B. L., Eldred, A. R., Roland, D. A., Underhill, D. B. Sr \& Harms, R. H. (1975). The dietary-fecal relationship of calcium and phosphorus levels in White Leghorn hens. Poultry Science 54, 1716-1718.

Günther, K. D. \& Al-Masri, M. R. (1988). Untersuchungen zum Einfluss einer variierten Phosphorversorgung auf den P-Umsatz und die endogene P-Ausscheidung beim wachsenden Geflügel mit Hilfe von ${ }^{32} \mathrm{P}$ (The influence of different phosphorus supply on phosphorus turnover in growing broiler chicks by means of ${ }^{32} \mathrm{P}$ isotope). Journal of Animal Physiology and Animal Nutrition 59, 132-142.

Günther, K. D. \& Tekin, C. (1968a). Untersuchungen über die Skelettentwicklung und Ossifikation beim Küken. 1. Mitt. Entwicklung und Mineralisierung des gesamtskelettes vom 1. bis 28. Lebenstag als Funktion der CaP.Versorgung (Development and calcification of the skeleton in chickens. 1. Development and calcification of the skeleton as a function of the Ca- and P-content in feed). Zeitschrift für Tierphysiologie, Tierernährung und Futtermittelkunde 23, 355-372.

Günther, K. D. \& Tekin, C. (1968b). Untersuchungen über die Skelettentwicklung und Ossifikation beim Küken. 2. Mitt. Die Vergleichende Ossifikation der einzelnen Skeletteile in Abhängigkeit von der Ca- P-Versorgung (Development and calcification of the skeleton in chickens. 2. The calcification in the individual parts of the skeleton, as the function of the $\mathrm{Ca}-$ and P-content in feed). Zeitschrift für Tierphysiologie, Tierernährung und Futtermittelkunde 23, 372-384.

Günther, K. D., Hermes, I. \& Abel, H. (1978). Zum Einfluss der Phosphorversorgung auf den Phosphorumsatz beim wachsenden Geflügel (The effect of phosphorus amount in the feed on phosphorus turnover in growing broiler chicks). Zeitschrift für Tierphysiologie, Tierernährung und Futtermittelkunde 40, 130-131.

Günther, K. D., Hermes, I., Eyo, S. E. \& Abel, H. (1982). Untersuchungen zur intermediären Verfügbarkeit und Verwerbarkeit von Futterphosphor beim wachsenden Geflügel. II. Zum Einfluss der futterphosphormenge (Evaluation of the intermediary availability and the efficiency of utilization of feed phosphorus in growing chickens. 2. The effect of the phosphorus amount in the feed). Zeitschrift für Tierphysiologie, Tierernährung und Futtermittelkunde 48, 260-266.

Hermes, I. (1977). Untersuchungen zur Frage der Phitinverwertung beim wachsenden geflügel in Abhängigkeit vom gesamtphosphorgehalt des Futters und dessen Anteilen an Phytinphosphor (The utilization of phytin by growing broiler chicks, as influenced by total phosphorus and phytin phosphorus amounts in the feed). PhD Thesis, University of Göttingen, Germany.

Hermes, I., Günther, K. D. \& Abel, H. (1983). Untersuchungen zur intermediären Verfügbarkeit und Verwertbarkeit von Futterphosphor beim wachsenden Gefiügel. III. Zum Einfluss des Ca:P-Gewichtsverhältnisses (Evaluation of intermediary availability and the efficiency of utilization of feed phosphorus in growing chickens. 3. The influence of the weight proportion between $\mathbf{C a}$ and $\mathbf{P}$ in the feed). Zeitschrift für Tierphysiologie, Tierernährung und Futtermittelkunde 49, 24-30. 
Hevesey, G. (1948). Radioactive Indicators, pp. 103-104. New York: Interscience Publishers Inc.

Hevesey, G. (1962). Adventures in Radioisotope Research, vol. 2, p. 548. Oxford, New York, London: Pergamon Press.

Hevesey, G., Hahn, L. \& Rebbe, O. (1939). Excretion of Phosphorus. Det kgl. Danske Videnskabernes Selekab, vol. 14, no. 3. Copenhagen: Biologiske Meddelelser.

Hurwitz, S., Dubrov, D., Eisner, U., Risenfeld, G. \& Bar, A. (1978). Phosphate absorption and excretion in the young turkey, as influenced by calcium intake. Journal of Nutrition 108, 1329-1335.

Huyghebaert, G., Keppens, L. \& de Groote, G. (1981). The effect of the Ca-content of the diet and of a thermal treatment of the P-sources on the P-utilization by broiler chicks. Archiv für Gefiügelkunde 45, $240-247$.

Lantzsch, H. J. (1961). Untersuchungen über die P-Absorption und P-Exkretion an graviden und laktierenden Sauen unter Verwendung des Radioisotopes ${ }^{32} \mathbf{P}$ (Studies on the absorption and excretion of phosphorus in lactating female pigs using the radioisotope ${ }^{32} \mathrm{P}$ ). $\mathrm{PhD}$ Thesis, University of Göttingen, Germany.

Scharifi, M. (1978). Untersuchungen zur Frage der Phytin-Verwertung beim wachsenden Geflügel in Abhängigkeit vom Gesamtphosphorgehalt und vom Ca:P-Verhältnis des Fütters (The utilization of phytin by growing broiler chicks, as influenced by total phosphorus and the $\mathrm{Ca}$ to $\mathrm{P}$ ratio of the feed). PhD Thesis, University of Göttingen, Germany.

Schöner, F.-J., Hoppe, P. P., Schwartz, G. \& Wiesche, H. (1993). Vergleich von mikrobieller Phytase und anorganischem Phosphat beim Masthahnenküken: Wirkungen auf die Mastleistungen und die Mineralstoffretention beim variierter Calcium-Versorgung (Comparison of microbial phytase and inorganic phosphate in male chickens. The influence on performance data, mineral retention and dietary calcium). Journal of Animal Physiology and Animal Nutrition 69, 235-244.

Schultz, E. \& Oslage, H. J. (1972). Untersuchungen zur intestinalen Hydrolyse von Inositphosphorsäuerester und zur Absorption von Phytinphosphor beim Schwein. 2. Mitt.: Untersuchungen zur Hydrolyse der Inositphosphorsäuerester im Verdauungstrakt des Schweines (Studies on intestinal hydrolysis of inositol phosphoric acid esters and phytin phosphorus absorption in pigs. 2. Hydrolysis of inositol phosphoric acid esters in pigs). Zeitschrift für Tierphysiologie, Tierernährung und Futtermittelkunde 30, 76-91.

Simons, P. C. M., Versteegh, H. A. J., Jongbloed, A. W., Kemme, P. A., Slump, P., Bos, K. D., Wolters, M. G. E., Beudeker, R. F. \& Verschoor, G. J. (1990). Improvement of phosphorus availability by microbial phytase in broilers and pigs. British Journal of Nutrition 64, 525-540.

Vemmer, H. \& Gütte, J. A. (1964). Bestimmung von ${ }^{32} \mathrm{P}$ mit Hilfe der Cerekov-Strahlung und eines Verbeserten inneren Standards (Evaluation of ${ }^{\mathbf{3 2}} \mathbf{P}$ using Cerenov radiation and an improved internal standard). Atompraxis $10,475-477$. 